\title{
Relationship between biochemical, environmental, and microbiological changes with the success rate of fertilization techniques
}

\section{Relação entre alterações bioquímicas, ambientais e microbiológicas e o sucesso da técnica de fertilização in vitro}

\author{
Érica Eugênio Lourenço Gontijo ${ }^{1}$, Mário Silva Approbato² \\ 1 Aluna de doutorado em Ciências da saúde pela UFG. Laboratório de Reprodução Humana HC/UFG. Email: \\ ericagontijo1@yahoo.com.br \\ 2 Doutor USP, FMRP. Laboratório de Reprodução Humana HC/UFG.
}

\begin{abstract}
The success rate for the evaluation of the results of techniques of Assisted Human Reproduction implies the occurrence of pregnancy with a live, healthy child. There are reports of the association between chemical and unhealthy environmental air conditions (bacteria, dust, particulates and volatile compounds) and reducing the success rate of embryo production and the occurrence of pregnancy. This paper reviews available information about the interference of biochemical, environmental and microbiological changes with the success of the assisted reproductive technique.

Key words: Assisted Human Reproduction, Environmental conditions, In Vitro Fertilization and environmental contamination, Clean Room In Vitro Fertilization.
\end{abstract}

\section{RESUMO}

A taxa de sucesso para a avaliação dos resultados das técnicas de Reprodução Humana Assistida implica na ocorrência de gravidez com nascimento de uma criança viva e saudável. Existem relatos da associação entre condições químicas e ambientais insalubres do ar (por exemplo, bactérias, poeira, materiais particulados e compostos voláteis) e a redução da taxa de sucesso na produção de embriões e na ocorrência de gravidez. Este artigo pretende revisar informações disponíveis sobre a interferência das alterações bioquímicas, ambientais e microbiológicas com o sucesso da técnica de fertilização assistida. Palavras-chave: Reprodução Humana Assistida, Condições ambientais, Fertilização in vitro e contaminação ambiental, Sala limpa Fertilização in vitro.

\section{INTRODUCTION}

The Assisted Human Reproduction (AHR) is basically a human intervention in the natural process of procreation, with the aim of enabling women with problems of infertility and sterility to satisfy the desire to achieve motherhood (Esteves, 2013).

The success rate for the evaluation of the results of the techniques of RHA implies the occurrence of pregnancy with a live, healthy child (Tonguc et al., 2010). Some researchers observed a decrease in the production of embryos and consequently reduction in pregnancy success when their production/manipulation occurs in places with unhealthy chemical and environmental conditions. With the introduction of the concept of clean room that reality has changed. However, few studies have reported the correlation between the levels of toxic (bacteria, dust, particulates and volatile compounds) and a decrease in the development of embryos (Esteves, 2013; Boone et al., 1994).

Gametes and human embryos cultured in vitro are extremely sensitive to fluctuations in temperature, humidity, light exposure, contaminants and physical trauma. Several studies suggest that toxic agents, bacteria, particles, dust and chemicals (VOCs), can affect the fertilization and embryo development (Esteves, 2013; RDC23, 2011; Martinez-Hurtado et al., 2010; International Organization for Standardization, 2009; Berneteix, 1998; Nolard, 1994).

Lacerda (2000) reports that this mechanism, together with the accumulation of $90 \%$ of recycled air, causes an increase in the number of microorganisms in order 1000-100000 times higher compared to the external environment. An increase of $1 \mathrm{~g} / \mathrm{m}^{3}$ respirable particles cause an increase in respiratory diseases in 3\%, impaired lung function, leading to mortality (Esteves, 2013).

This review aims to condense information available about the interference of biochemical, environmental and microbiological changes in the success of the assisted reproductive technique.

\section{AIR QUALITY IN AIR-CONDITIONED ENVI- RONMENTS AND ITS INFLUENCE ON THE OCCURRENCE OF INFECTIONS}

Biological contaminants and bio aerosols such as fungi, bacteria, algae, mites, amoebae use particulate matter (pollen, insect fragments, flakes of human skin and hair) as substrate, where they multiply, doubling the population every 20 seconds, therefore depending on the cell parasitism for playback. Outbreaks may be associated with contamination of these aerosols (Hurtado-Martinez et al., 2010).

In Brazil, hospital areas are separated considering the proposal by Spaulding (Brazil, 1985) who considered the potential risk for the occurrence of infection, grouping them into classification: non-critical areas, which are not occupied by patients, such as offices and warehouses, semi-critical areas occupied by those patients who do not require intensive care or isolation, such as wards and outpatient clinics; critical areas, those that offer potential risk for infection, or invasive procedures are the presence of immunocompromised patients or by occupational risk related to the handling of infectious substances.

For the American Society for Testing and Materials (2009), sources of particles capable of carrying microorganisms causing contamination are classified into internal and external. Among the internal sources include people, fans, air conditioners, humidifiers and nebulizers, floors and potted plants and certain types of food. Regarding foreign sources are the soil, water, decaying matter, dust from construction and remodeling.

In indoor air, microbiological contamination can be a serious problem, and a number of factors allow the growth and release of these biological agents in the air. High humidity, poor ventilation, ventilation and air conditioning that have water or condensation in some parts (cooling towers) facilitate the growth and distribution of microorganisms.

Among these factors, the high relative humidity is one of the most important, because it allows the increase of popu- 
lations of mites and mold growth on damp surfaces. A study by Esteves (2013), describes the prevalent microorganisms in air-conditioned indoors, it stands between these bacteria: Legionella pneumophila, Bacillus sp, Flavobacterium sp, Pseudomonas aeruginosa, Staphylococcus aureus, Mycobacterium tuberculosis, Neisseria meningitidis, Streptococcus pneumoniae, Actinomyces sp. Fungi: Paracoccidioides $\mathrm{sp}$, Penicillium sp, Cladosporium sp. And Fusarium sp and the influenza virus and respiratory syncytial virus. Eickhoff (1994), cites Legionella sp, Clostridium sp, Nocardia sp relate to the transmission of infection caused by air conditioning. As to fungal contamination, Aspergillus sp is the most important (Nolard, 1994; Berneteix, 1998). The sources of contamination by spores of Aspergillus sp are potted plants, paper packaging, construction and renovation, and certain foods such as flour, bread, dried chili powder, lyophilized powders and raw food in the form of tubers.

\section{CONTAMINATION OF AIR AND THE MICRO- BIAL CULTURES OF EMBRYOS IN ASSISTED REPRODUCTION LABORATORY}

There are reports of the association between chemical and unhealthy environmental air conditions (bacteria, dust, particulates and volatile compounds) and reducing the success rate of embryo production and the occurrence of pregnancy (Martinez-Hurtado et al., 2010, RDC23, 2011, International Organization for Standardization, 2005).

In 1994, William R. Boone detected during the expansion of his assisted reproduction laboratory Hospital in Greenville, South Carolina in the United States, that the reform increased the detectable odors in the laboratory. Increased levels of dust and other particles associated with the installation of the equipment have been observed, as well as odors from paint and glue tiles. Simultaneously the clinical pregnancy rate reduced and the success of in vitro fertilization procedures decreased from 35\% (25 of 71) in 1993 to $16 \%$ (11 of 68). Thus, it demonstrated that the air quality affects embryo development in assisted reproduction clinics. The improvement of air quality and reduction of odors promoted a gradual increase in the pregnancy rate in the following years. Pregnancy rates increased slightly in $1995(20 \%)$ after the installation of the clean room and then dramatically in 1996 and 1997 (32\% and 59\%) respectively.

While microbial contamination of embryo culture plates occurs occasionally even with the use of media containing penicillin and streptomycin, a growing number of infections recently has been observed in human reproduction laboratories.

Peter et al., (2007), for a period of 8 years (January 1997 to December 2004), noted that in 13,977 IVF cycles, microbial contamination was observed in $95(0.68 \%)$ of the culture plates by microorganisms. All infections were confirmed by microbiological investigations. Relevant details of both cycles of fertility treatment and microbial strains isolated and identified were investigated. The main identified microorganisms were Escherichia coli $(n=56,58.9 \%)$ and Candida species ( $n=24$, $25.3 \%)$. Strains of E. coli isolated, $41(73.2 \%)$ were resistant to both antibiotics used in the culture and $13(23.2 \%)$ were resistant to penicillin or streptomycin. In all bacterial strains the resistance was $61.4 \%$ for both and $30 \%$ of the antibiotics used.

\section{ANVISA RESOLUTION ON INTERNAL CONTROL OF AIR IN ASSISTED FERTILIZATION LABORATORIES}

While the need for specific technical requirements relating to air quality on human reproduction laboratories has been widely debated, most researchers recognize the importance of a more rigorous management of laboratories and also minimum air quality standards should be implemented. To this, ANVISA published the RDC N ${ }^{\circ} 23$ of 27 May 2011 laying down clear and strict standards to control the internal environment of the assisted reproductive laboratory.

In summary, all IVF laboratories should have an HVAC system that maintains positive air pressure relative to the surrounding environments, conditions of temperature control between $23^{\circ} \mathrm{C}$ to $27^{\circ} \mathrm{C}$, relative humidity $40 \%$ to $70 \%$, flow minimum total of
45 air $\left(\mathrm{m}^{3 / \mathrm{h}}\right) / \mathrm{m}^{2}$, minimum outside air flow rate of $15\left(\mathrm{~m}^{3 / \mathrm{h}}\right) /$ $\mathrm{m}^{2}$ and minimum air supply with filtering in G3+ F8+ activated charcoal filters. The environment can not possess any hidrosanitary installation, such as sinks, drains or sinks. Handling of samples should be performed in a clean area classified at least as an ISO Class 5 (RDC23, 2011).

It is believed that the implementation of strict control of air quality, as required by RDC23 is likely to have a negligible impact on the risks of contamination of the culture of embryos, however the results should be analyzed only in the near future in Brazilian laboratories.

\section{CONCLUSION}

In a general manner, this shows the influence of chemical and environmental unsanitary conditions with the reduced embryo production and consequently reduction of successful pregnancy. With clean air and reduction of odors, there is a gradually increased rate of pregnancy. There is the need to expand the knowledge about the changes caused by environmental and atmospheric factors within the physical premises where manipulation of gametes and embryos occurs. It is believed that control of the air, temperature, humidity, contamination of culture media and air flow are key factors for standardization of assisted reproduction procedures and results.

In Brazil there is little information about the influence of the environment on the success of assisted reproduction techniques, therefore, the formation of databases that contribute to the updated information about the success of IVF, can contribute to more efficient management that will subsidize more efficient strategies to control contaminants in handling human embryos environments currently under the responsibility of ANVISA, improving the quality of assisted reproductive techniques in Brazil.

\section{REFERENCES}

American Society for Testing and Materials, 2009. Test Method D346799: Standard Test Method for Carbon tetrachloride activity of activated carbon (ASTM D3467-04). Available from: <http://www.astm.org/Standards/D3467.htm/> (accessed 08/08/13).

ANVISA. Brazilian National Agency for Sanitary Surveillance, 2006. Resolution RDC no. 33 of the Board of the National Health Surveillance Agency ( amended by RDC23 of 27 May 2011 on setting standards of quality and safety for the donation, procurement, testing, processing, preservation, storage and distribution of human tissues and cells). Available from: <http://bvsms.saude.gov.br/bvs/saudelegis/anvisa/2011/ res 0023_27_05_2011.html/> (accessed 11/14/13).

Berneteix MT. Un combat dans lair du temps la lute contre Aspergillus. Rev.Infirm. 1998, 44:12-18.

Boone WR, Johnson JE, Locke AJ, Crane MM, Price TM. Control of air quality in an assisted reproductive technology laboratory. Fertility and Sterility. 1994,71:1-12.

Brazil. Ministry of Health Coordination Control of Hospital Infection. Manual of Infection Control. Brasilia, 1985.

Eickhoff TC. Airborne Nosocomial Infection: a contemporary perspective. Hospital Infection Control and Epidemiology. 1994; 15(10):663-672.

Esteves SC, FC Benedict. Implementation of air quality control in reproductive laboratories in full compliance with the Brazilian Cells and Tissue germinative Directive. Reproductive BioMedicine Online. 2013;26:9-21.

International Organization for Standardization. NBR ISO 14644-3 on cleanrooms and associated controlled environments-Part 3: Test methods. Brazilian Association of Technical Standards (ABNT), Brasilia, DF, Brazil, 2009.

Lacerda RA. Surgical Center. In: Fernandes ATF. Hospital infection and its interfaces in healthcare. Sao Paulo: Atheneu, 2000:1307-22

Martinez-Hurtado JL, Davidson CAB, Blyth J, Lowe CR. Holographic detection of hydrocarbon gases and other volatile organic compounds. Langmuir: 2010; 26:15694-99.

Nolard N. Les liens between les risques asdpergillose et la contamination the environnement. Pathol.Biol. 1994;7(42):706-10.

Peter M, Kastrop M, Lia AM, Dagmar R, Gutknecht M. Microbial contamination of embryo cultures in an ART laboratory: sources and management. Hum Reprod. 2007;22(8):2243-8.

Tonguc And Var T, Onalan G, Altinbas S, Tokamak A, Karakas N, Gulerman C. Comparison of the effectiveness of single versus double intrauterine insemination with three different timing regimens. Fertility and Sterility, American Society for Reproductive Medicine. 2010; 94:3-9 